\title{
Sea Level Rise and Shifting Maritime Limits: Stable Baselines as a Response to Unstable Coastlines
}

\section{Signe Veierud Busch ${ }^{\star}$}

\author{
KG Jebsen Centre for the Law of the Sea, UiT the Arctic University of Norway
}

\begin{abstract}
It is a long known fact that climate change will result in sea level rise and dramatically changed coastlines for a number of coastal States, and the physical consequences of sea level rise are most likely unavoidable for several coastal States due to their geographical location, size and topography. It is highly debatable whether the Law of the Sea Convention is equipped for dealing with the current challenges of sea level rise and maritime limits, and it may be argued that its rule of ambulatory baselines may contribute to loss of territory, relocation of maritime zones, uncertainty and instability.

This article investigates the current status of the law regulating maritime limits which may be affected by sea level rise, and argues that the best solution is to adapt the law within the current legal framework of the Law of the Sea, by undertaking a liberal interpretation of the already existing provisions of the LOSC, instead of invoking the amendment procedures of the LOSC, a new supplementary agreement or creating new customary law. In particular, the article explores the option of re-interpreting the law of baselines in Article 7, offering an adapting measure that mitigates the climate change effects on sea level rise. It is argued that a liberal interpretation of the LOSC can contribute to increased stability and juridical protection of the maritime entitlements for some of the States suffering the consequences of sea level rise.
\end{abstract}

Keywords: baselines, sea level rise, ambulatory limits, delta baselines, stability, adaptation, climate change, LOSC, vulnerable States, small island States, unstable coastline, straight baselines

Responsible Editor: Øyvind Ravna, UiT - The Arctic University of Norway, Tromsø, Norway.

Received: February 2018; Accepted: May 2018; Published: June 2018

\footnotetext{
${ }^{\star}$ Correspondence to: Signe.busch@uit.no 


\section{Introduction}

For three decades, scientists have warned us of climate change, global warming and sea level rise. ${ }^{1}$ In its fifth report, the Intergovernmental Panel for Climate Change (IPCC) estimated a sea level rise from the 1986 level to between 26 and 82 centimetres by the end of this century. ${ }^{2}$ In addition, regional sea level changes will differ substantially from the global average. ${ }^{3}$

For low-lying coastal States, the consequences of such a rise in sea level will be catastrophic. It is estimated that a one-metre sea level rise will flood territory that is presently home to more than 60 million people. ${ }^{4} \mathrm{~A}$ one-metre sea level rise will submerge approximately fifteen percent of Bangladesh and displace more than seven million inhabitants in the Mekong delta area of Vietnam alone. ${ }^{5}$ The low-lying areas that are not entirely submerged will be particularly vulnerable to periodic flooding and exposed to extreme weather conditions; saline intrusion will affect agricultural land and contaminate freshwater sources. ${ }^{6}$ Low-tide elevations, reefs, rocks and low-lying islands may be flooded or damaged by erosion. Small island States may partially or fully disappear due to sea level rise, or they may be rendered uninhabitable. The changing coastline affects the location of a number of maritime limits. National boundaries may be affected, and in certain instances particularly vulnerable States risk losing land territory that is the basis for their existence. ${ }^{7}$

Ever since the IPCC issued its first report in 1990, legal scholars have pointed to the insufficiencies of the Law of the Sea Convention (LOSC) ${ }^{8}$ as regards the law on baselines, and have called for a change. ${ }^{9}$ Amongst others, Caron ${ }^{10}$ and Soons ${ }^{11}$ published their research on the effect that sea level rise would have on maritime boundaries. ${ }^{12}$ They observed that the legislation concerning the establishment of the different maritime limits was in no shape to tackle the expected sea level rise, and they expressed concern about how the law of the sea could adapt to the changes. They called for change, either by means of amending the rules of the LOSC, a new supplementary agreement, or new customary law.

Close to thirty years later, the same questions are raised, and the same arguments made. The legal framework remains unchanged. This article sets out to discuss the current status of the laws on maritime limits that may be affected by sea level rise and focuses on measures that may be taken within the current legal framework to adapt to sea level rise, instead of calling for amendments or a new supplementary agreement, or creating new customary law. More concretely, the question raised is whether we can adapt to sea level rise by means of re-interpreting the law on baselines, and in particular Article 7(2) of the LOSC on delta baselines.

In the following, I will first briefly discuss the issue of sea level rise in connection with maritime boundaries. Next, I will discuss the consequences of sea level rise for particularly vulnerable States, before I discuss the scope of the application and interpretation of Article 7. I will discuss the extent to which more stable baselines can be the appropriate response to unstable coastlines. 


\section{S.V.Busch}

\section{Ambulatory baselines and shifting maritime zones}

To discuss the effects of sea level rise on maritime boundaries, we must first explore the legal framework applicable to maritime boundaries. The waters off a coastal State are divided into different maritime zones, where the coastal State enjoys various degrees of sovereignty, sovereign rights, and legislative and enforcement jurisdiction. The outer limit of each maritime zone is, in most instances, drawn based on a distance criterion measured from the baselines. Hence, the baselines separate the internal waters from the territorial sea, and they serve a much more extensive purpose. Article 5 of the LOSC provides that the normal baseline "is the low-water line along the coast as marked on large-scale charts officially recognised by the coastal State".

However, the normal baseline is affected by several geographical circumstances, which allow for the application of special provisions. If any naturally formed low-tide elevations are situated wholly or partially within twelve nautical miles $(\mathrm{nm})$ from the mainland or an island, the low-water line on that elevation may be used as the baseline for measuring the breadth of the territorial sea. ${ }^{13}$ In certain instances, the LOSC also provides an option for the coastal State to establish straight baselines. ${ }^{14}$ Such baselines allow the coastal State to draw straight lines joining appropriate points in cases where the coastline is deeply indented and cut into, or there is a fringe of islands along the coast or in its immediate vicinity. Although it may be possible to draw normal baselines along the low-water line in such instances, this is not practical, and makes it difficult to ascertain the location of the outer limit of the territorial sea. Straight baselines are drawn by joining appropriate points, which do not depart to any appreciable extent from the general direction of the coast, and include only those sea areas sufficiently closely linked to the land domain. ${ }^{15} \mathrm{~A}$ straight baseline cannot be drawn to and from low-tide elevations, unless lighthouses or other installations, which are permanently above sea level, have been built on them, or the drawing of such a baseline has received general international recognition. ${ }^{16}$ The reason for this is presumably to prevent baselines from being drawn too far seawards from the coast, in adherence with Article 7(3) of the LOSC. In addition, straight baseline may not cut off the territorial sea of another State from the high seas or EEZ. ${ }^{17}$ The LOSC also provides separate rules regarding how to establish baselines enclosing rivers, bays and harbor works.

Since the baselines are established along the low-water mark or on the basis of lowtide elevations, the baselines constitute so-called ambulatory limits. This means that baselines will shift due to coastal realignment. This is an example of the principle that "the land dominates the sea". ${ }^{18}$ The shifting baselines directly affect the location of the remaining maritime limits.

Article 3 of the LOSC provides that the breadth of the territorial sea shall not exceed $12 \mathrm{~nm}$ measured from the baselines. Similarly, Article 33 provides that the contiguous zone may not extend beyond $24 \mathrm{~nm}$ from the baselines, whilst Article 57 provides that the EEZ shall not extend beyond $200 \mathrm{~nm}$ from the baselines. If the 
baselines of a coastal State move as a result of sea level rise, the above-mentioned limits must also be relocated. This does not diminish the size of each specific maritime zone, as both the inner and outer limits of the zone are moved. However, this may have severe consequences for the coastal State, as different maritime zones are subject to different legal regimes. A relocation of the different zones affects the coastal State's legislative, jurisdictional and enforcement powers. Overall, a landward relocation on the different maritime zones will diminish the sovereign area of the coastal State.

The territorial sea is part of the coastal State's territory and is subject to its exclusive sovereignty. ${ }^{19}$ Other States enjoy the right of innocent passage, but they are subject to the coastal States' laws and regulations. Article 3 of the LOSC provides that the breadth of the territorial sea shall not exceed $12 \mathrm{~nm}$ measured from the baselines. This means that, if the baselines move landwards, areas that originally were part of the territorial sea will instead become part of the EEZ and be subject to the rules in part 5 of the LOSC.

In a belt of sea contiguous to the territorial sea, the coastal State may exercise the control necessary to prevent or punish the infringement of customs, fiscal, immigration and sanitary laws in its territory and territorial sea. Article 33 provides that the contiguous zone may not extend beyond $24 \mathrm{~nm}$ from the baselines. Consequently, the entire contiguous zone will be relocated when baselines move.

The most severe effects of shifting maritime limits will probably occur when an area that was previously part of the EEZ becomes high seas. Article 57 provides that the EEZ shall not extend beyond $200 \mathrm{~nm}$ from the baselines. In the EEZ, the coastal State possesses sovereign rights over living and non-living natural resources in the sea-bed and water column, and all other states possess the freedoms of navigation and overflight. When part of the former EEZ becomes high seas, it is open to all states, which can then exercise the freedoms of navigation and overflight; the freedom to lay submarine cables and pipelines; the freedom to construct artificial islands and other installations; and the freedom to fish and conduct scientific research. The relocation of the EEZ limit may cause stocks that primarily occurred within the EEZ of the coastal State to occur both within the EEZ and the adjacent high seas. In such cases, the coastal State and other States fishing the same stock are obligated to agree upon the measures necessary for the conservation of the stock in the adjacent area. Likewise, transboundary stocks and straddling stocks previously traversing between the EEZ and the high seas may stop occurring in the EEZ, which would require the coastal State to adjust its total allowable catch and quotas and could have severe economic implications. The status of non-living resources of the EEZ is slightly different, since such resources are also regulated as part of the continental shelf regime.

Finally, the question arises whether the location of baselines is relevant to the location of continental shelf limits. If the continental margin of a coastal State does not extend to the distance of $200 \mathrm{~nm}$ from the baselines, a $200 \mathrm{~nm}$ continental shelf will be measured from the baselines. Article 76(5) ofThe LOSC also provides a so-called constraint line for cases in which the continental margin continues far seawards of the $200 \mathrm{~nm}$ line, providing that "the outer limit of the continental shelf shall not 


\section{S.V.Busch}

exceed $350 \mathrm{~nm}$ from the baselines, or shall not exceed 100 nautical miles from the 2500 mater isobath". This suggests that the outer limit of the continental shelf in certain cases may also be measured from the baseline. If the constraint line is not invoked, the continental shelf limits are established along the outer edge of the continental margin in accordance with Article 76(1).

It can be argued that continental shelf limits are in a unique position, as Article 76(9) specifically provides that "[t]he coastal State shall deposit with the SecretaryGeneral of the United Nations chars and relevant information (...) permanently describing the outer limits of the continental shelf". The reference to "permanently describing" has been the subject of debate among legal scholars, but there seems to be a mutual understanding that such limits are unalterable and accordingly not vulnerable to sea level change. ${ }^{20}$

Further, the question should be raised if "permanently established" limits refers only to outer continental shelf limits established along the outer edge of the continental margin, or if it also applies to continental shelf limits based on the distance criterions in Article 76. Although the wording of Article 76(9) may be read as a continuation of the "final and binding" requirement included in paragraph (8) for limits established along the continental margin, it is important to note that the reference to "permanently describing" is included in a separate provision in the article and not as part of paragraph (8). The wording of paragraph (9) makes no distinction between the continental shelf within or beyond $200 \mathrm{~nm}$, but merely speaks of "the outer limits of the continental shelf", a phrase that encompasses all continental shelf delineation limits. ${ }^{21}$ In fact, none of the provisions in Article 76, except for paragraph (8), makes any distinction between the $200 \mathrm{~nm}$ continental shelf and the continental shelf beyond that distance. Similarly, Article 83 on continental shelf delimitation makes no such distinction. Deciding that only continental shelf limits beyond $200 \mathrm{~nm}$ are permanent, whilst ordinary $200 \mathrm{~nm}$ continental shelf limits are ambulatory, has no legal basis and would seem unjust. ${ }^{22}$ The effect of Article 76(9) is accordingly that all continental shelf limits are permanently established and will not be affected by sea level rise and shifting baselines.

\section{States Particularly Vulnerable to Sea Level Rise}

The general consequences of sea level rise for the maritime zones of coastal States discussed above result in moving baselines and shifting maritime limits that affect the sovereignty and jurisdiction of coastal States.

However, some States are particularly vulnerable to sea level rise for several reasons. They are vulnerable due to their geographical location, size and topography. Large areas of low-lying States will be submerged, and the low-lying areas that are not entirely submerged will be particularly exposed to extreme weather conditions and vulnerable to periodic floods. Saline intrusion will impact agricultural land and contaminate freshwater sources. Coastal ecosystems, coastal infrastructure and human settlement are at risk. 
Another category of particularly vulnerable States are small island States. In addition to the risks of submerged areas, floods and saline intrusion, low-lying islands are in an even more critical position, as they risk experiencing a significant reduction in the spatial extent of marine areas subject to national jurisdiction. ${ }^{23}$ Changed baselines will impact national claims of maritime jurisdiction and will have economic and jurisdictional consequences. It follows from Article 121(3) of the LOSC that "rocks which cannot sustain human habitation or economic life of their own shall have no exclusive economic zone or continental shelf". If an island is rendered uninhabitable due to sea level change, coastal States are at risk of losing large areas of economic zones and potentially a continental shelf that extends far beyond $200 \mathrm{~nm}$ from the baselines of the specific island. ${ }^{24}$ If the entire land territory of the coastal State is submerged, the question arises whether that State can continue to exist as a State without a territory. ${ }^{25}$ However, this topic goes beyond the scope of this paper.

States may also be particularly vulnerable to sea level rise for legal reasons. Soons argues that, if two coastal States are situated less than $400 \mathrm{~nm}$ from each other (for EEZ and continental shelf delimitation) or less than $24 \mathrm{~nm}$ from each other (for territorial sea delimitation), and they have entered into a boundary agreement in which the boundary has been drawn between basepoints determined by geographic coordinates, it must "in principle be concluded that changes in the geographical configuration as a result of sea level rise will not result in changes in the boundary line". ${ }^{26}$ Similarly, boundaries established by international adjudication are considered final, binding and not appealable. ${ }^{27}$ States that have not entered into delimitation agreements with neighboring States or established their boundaries in accordance with international adjudication, are more vulnerable to the effects of sea level rise.

\section{Stable Baselines as Response to Unstable Coastlines}

\subsection{Introduction}

The major weakness of the Law of the Sea Convention in relation to the current challenge of sea level rise and maritime limits is the rule of ambulatory baselines, which contributes to loss of territory, relocation of maritime zones, uncertainty and instability.

A number of scholars have proposed solutions to the problem of climate-induced sea level rise. Schofield and Freestone point out that the easiest option is to do nothing. Rather than protect the coast and try to stabilize the limits, the State can choose to accept the consequences of climate change, plan their retreat and relocate the limits. ${ }^{28}$ However, it is quite obvious that the costs of such a strategy would be highly disadvantageous. Schofield and Freestone suggest that a State can seek to protect its coast by building structures to prevent erosion, saline intrusion, floods, etc. Other authors, such as Caron and Soons, call for raising the question whether the provisions of the LOSC need to be amended. 


\section{S.V.Busch}

However, the amendment procedures of the LOSC have never been initiated, and it does not seem likely that any State party will seek to change the LOSC rules on baselines by invoking the amendment procedures. ${ }^{29}$ This article therefore focuses on the possibilities of adapting to the consequences of climate change and sea level rise whilst operating within the current legal regime.

\subsection{Delta baselines as a separate category of straight baselines}

Some coasts are more vulnerable to sea level fluctuation than others due to the nature of their coastline. Low-lying States with large river deltas, such as Bangladesh and Vietnam, are examples of such vulnerable States. The LOSC provides a special regime of straight baselines in areas where a delta and other natural conditions render the coastline highly unstable. In such situations, the appropriate points may be selected along the furthest seaward extent of the low-water line. This provision is the result of an informal position paper on the issue of baselines submitted by Bangladesh during UNCLOS III, which describes the particular challenges of Bangladesh, with its highly shifting and unstable baseline, where no stable water line or demarcation of landward and seaward areas exists. Therefore, Bangladesh suggested including a provision on deltas:

(...) if the water adjacent to the coast is marked by continual process of alluvion and sedimentation creating a highly unstable low water line the method of straight baselines joining appropriate points on the coast or on the coastal waters may be employed in drawing the baseline (..... ${ }^{30}$

When the informal consultative group on baselines provided the revised consolidated text on baselines, the provision on deltaic baselines was formulated in its current form "where because of the presence of a delta [and] other natural conditions the coastline is highly unstable, the appropriate points may be selected along the furthest seaward extent of the low-water line". ${ }^{31}$ Although Article 7(2) on delta baselines was drafted with the specific case of the Ganges/Brahmaputra River Delta in mind, it may also be applied to other deltaic countries, such as Burma, Egypt, Nigeria and Vietnam.

Some authors have raised questions about the relationship between Article $7(1)$ and (2), asking whether application of paragraph 2 also requires that the coastline be deeply indented and cut into or where there is the presence of a fringe of islands as prescribed in paragraph $1 . .^{32}$ The United Nations Office for Ocean Affairs and the Law of the Sea ${ }^{33}$ provided in its study on baselines that "this paragraph is subordinate to paragraph 1 and is not an alternative to it. In other words, for paragraph 2 to apply, the coastline of the delta must satisfy the conditions set out in paragraph 1 ". ${ }^{34}$ The majority of legal scholars have oriented in the same direction. Reisman andWesterman observe that " $[\mathrm{t}]$ his provision does not constitute a discharge from the preliminary geographical requirements of Article 7(1). These must still be fulfilled before the claimant state may proceed to Article 7(2)." ${ }^{35}$ Twenty years later, Schofield and Sas 
similarly observed that " $[\mathrm{t}]$ he remainder of article 7 can be viewed as being dependent on this first paragraph, providing guidance on how straight baselines are to be defined but not in itself offering justifications for their construction". ${ }^{36}$ Churchill and Lowe note that it is not clear whether Article 7(2) is laying down a third kind of coastline in addition to deeply indented coasts and coasts fringed with islands, or if paragraph 2 applies only to deltas on coasts that fall into the categories of Article 7(1). Still, they argue that the drafting history of Article 7 suggests that paragraph 2 is intended to apply to the latter, thereby making paragraph 2 subordinate to paragraph $1 .^{37}$

Prescott and Schofield do not express any concern about the ambiguity between paragraphs 1 and 2, and observe that the discussion is mainly of an academic nature. They argue that the countries that possess deltas will be untroubled by the relationship between paragraphs 1 and 2 based on a prediction that deltas characteristically have distributaries that can be regarded as deep indentions or that the outer edge of the delta is formed by islands, which can be considered a fringe. ${ }^{38}$ They observe that Bangladesh, Venezuela and Vietnam could justify straight baselines around the edge of their major deltas on the ground of being deeply indented or fringed with islands, or both.

Hoque, who represents a minority amongst scholars, raises the timely question: if the deltaic coast is highly indented or fringed by a number of islands, then what is the necessity of paragraph 2, if straight baselines can be drawn by the deltaic State under paragraph 1 ? $^{39} \mathrm{He}$ continues by observing that, "if the retreating deltaic coast is neither highly indented nor fringed by islands, this paragraph cannot give them any protection to the interest of that coast, which is against the objective of the inclusion of this paragraph". ${ }^{40}$ Hoque accordingly seems to argue that, if paragraph 2 is considered subordinate to paragraph 1, paragraph 2 is restricted from serving its purpose. Instead, paragraph 2 should be read independently of paragraph 1 .

In 2012, the International Law Association's (ILA) Committee on Baselines under the International Law of the Sea had its mandate expanded for four additional years to consider, amongst other issues, " $[\mathrm{t}]$ he interpretation and relevant state practice of Article 7 of the [LOSC] regarding the method adopted by States of drawing straight baselines". ${ }^{41}$ Whilst the ILA Committee acknowledge that there is no agreed single interpretation of Article 7, the Committee is at odds with the majority of legal scholars in their view that paragraph 2 is subordinate to paragraph 1 :

The Committee is of the view that Article 7(2) is to be read independently, and not cumulatively, with Article 7(1) and notes the historic basis for this provision is separate and distinctive from the criteria outlined in Article 7(1). ${ }^{42}$

The Committee is clear that "[t]hese criteria are not cumulative and any one of these three geographic circumstances will be sufficient for the coastal State to become entitled to use the straight baseline method". ${ }^{43}$ The Statement of the ILA Committee 


\section{S.V.Busch}

is inconsistent with previous academic interpretation practice, which to date has been justified in the interpretation put forward by the UN Study. Unfortunately, the ILA Committee does not comment upon the parts of the UN study which argue for the opposite interpretation of paragraph 2, or on previous interpretative practice. Instead, it bases its interpretation on the core of the UNCLOS negotiations, recalling that paragraph 2 was added to the convention text based on a proposal by Bangladesh during the negotiations. ${ }^{44}$ The main purpose of Bangladesh's proposal was to lower the threshold for deltaic States to establish baselines which take into account the special challenges of their coastal areas, not to raise the threshold even higher. Keeping in mind the purpose for the inclusion of Article 7(2) in the first place, based on the Bangladeshi initiative, it seems clear that Article 7(2) was not intended to be subordinate to paragraph 1 of the same Article.

In an era of sea level rise, it is more than timely to reach a conclusion on how paragraph 2 and its relationship to paragraph 1 should be interpreted. For States vulnerable to sea level change seeking to secure their maritime entitlements, it is crucial to know with which conditions they must be in compliance in order to establish deltaic baselines.

\section{3 "[A]nd other natural conditions"?}

With sea level rise threatening a number of coastlines, vulnerable States are expected to raise the question whether sea level rise resulting in a changing coastline may be considered as "other natural conditions", thereby potentially allowing them to draw a deltaic baseline around their coast regardless of the actual presence of a delta.

The phrase "other natural conditions" was not part of Bangladesh's proposal, but was added by the informal consultative group. ${ }^{45}$ The formulation of Article $7(2)$ has been described as unclear 46 , "not very well drafted" 47 , "obscure" 48 and "ambiguous" 49 in the literature, and it is not at all clear what would constitute such "other natural conditions".

In its study on baselines, the United Nations Office for Ocean Affairs and the Law of the Sea observed that "paragraph 2 of the Article refers to 'a delta and other natural conditions' so that for this paragraph to apply there must be a delta" (emphasis added)..$^{50}$ This interpretation is based on a strict literal interpretation of the provision, in which the word "and" suggests that the conditions are cumulative.

Bird and Prescott observe that there is disagreement about whether a delta must be present, or whether other highly unstable coasts can be treated under Article $7(2)$. They point out that, whilst "the English version and every other official translation except Russian insists on the presence of a delta[, $t$ ]he Russian version, like the original draft in the Informal Single Negotiating Text, refers to 'deltas or other natural conditions". ${ }^{51}$ Stoutenburg acknowledges that the original draft of the provision causes confusion, but maintains that the drafters' intent was to create a "Bangladesh exception", suggesting that the presence of a delta is required to establish straight baselines subsequent to Article $7(2) .{ }^{52}$ 
Churchill and Lowe assert that the inclusion of the phrase 'and other natural conditions' "appears to refer to causes of coastal instability other than deltas". ${ }^{53}$ This suggests that the presence of a delta or other natural conditions rendering the coastal line highly unstable is an alternative criterion. Roach and Smith similarly replace the phrase "and other natural conditions" with "or other natural conditions" (emphasis added), suggesting that they interpret them as two alternative reasons for highly unstable coastlines. ${ }^{54}$

The ILA Committee on Baselines under the International Law of the Sea also uses the terminology "the presence of a delta or other natural conditions" when it lists the instances under which a coastal State can rely upon the method of straight baselines (emphasis added). ${ }^{55}$ Interestingly, the ILA Committee maintains that there are three alternative geographical circumstances which can entitle the coastal State to use the straight baseline method. The first is a deeply indented coastline; the second is a fringe of islands along the coast; and the third is the presence of a delta or other natural conditions rendering the coastline highly unstable. ${ }^{56}$ The fact that ILA operates with three instances of straight baselines, instead of four, suggests that it interprets Article 7(2) as one geographic circumstance and that "delta" and "other natural conditions" are cumulative requirements. The fact that the ILA replaces the word "and" with the word "or", seemingly without ascribing it a different meaning, leads to unnecessary confusion, although it also paints an accurate picture of the current legal situation.

A similar discussion came up in the South China Sea award, during which the tribunal discussed whether the word "or" between the phrases "cannot sustain human habitation" and "economic life" entails that these requirements are cumulative or alternative. ${ }^{57}$ The tribunal concluded that "or" meant that the phrases were alternative requirements, but it also noted that the two terms in practice were closely interlinked, admitting that "the two will in most instances go hand in hand". Oude Elferink critically observes that the tribunal in practice interprets the terms as one being ancillary to the other instead of two requirements on equal footing. ${ }^{58}$ Common to both Article 7(2) and Article 121 is that the different interpretations of the terms "and" and "or" will have large consequences for the States concerned and therefore need more clarification than is currently offered.

In an attempt to set aside the vagueness and obscurity in the phrase "delta and other natural conditions", it can be argued that the decisive requirement in Article $7(2)$ is not the presence of a delta or other natural conditions, but rather that "the coastline is highly unstable". If the unstable coastline is the decisive criterion imbedded in Article 7(2), the instability would have to be a result of "the presence of a delta and other natural conditions". Whereas the United Nations Office for Ocean Affairs and the Law of the Sea's study on baselines defined a delta as "a tract of alluvial land enclosed and traversed by diverging mouths of a river", ${ }^{59}$ the UN study did not define "natural conditions". Prescott and Schofield discuss what would constitute "natural conditions" and observe that the term can be interpreted either as a reference to other coastal landforms or as a reference to the process affecting the size and 


\section{S. V. Busch}

configuration of deltas. They argue that it should be up to the States to select whether to interpret other natural conditions as landforms or processes..$^{60}$ Can sea level rise be considered such a process?

When the straight baseline regime was negotiated, sea level rise due to climate change was not an issue. However, as the phrase "natural condition" is very vague, it can be argued that sea level rise is a natural condition, which makes the coastline of low-lying States unstable. In 1989, Bird and Prescott noted that "we believe that more countries will seek to use Article 7 to minimize the effects of baselines of raising sea levels" ${ }^{61}$ Similarly, Churchill and Lowe observe that Article 7(2) "may be important in the future if predictions of a significant rise in the sea levels as a result of global climate change are fulfilled (...)". ${ }^{62}$ Schofield and Freestone observe: "Although this provision was drafted for specific circumstances, it has long been recognized that it could be used in response to sea level rise". ${ }^{63}$ Whereas a number of legal scholars assert that Article 7(2) may be used to draw straight baselines in response to sea level rise, it is remarkable that none of them provide any reasoning for this assertion.

Read in conjunction with the previous discussion, a liberal interpretation of Article 7 (2) would mean that coastal States may draw straight baselines along their coasts without having a deeply indented coastline, a fringe of islands, or the presence of a delta. The actual requirement for establishing deltaic baselines would be the existence of another natural condition that renders the coastline "highly unstable". Although perhaps not in accordance with the content of the Bangladesh proposal, such an interpretation is in accordance with the overall ambition of the LOSC, namely to stabilize the world's oceans and to contribute to the progressive development of the law of the sea. ${ }^{64}$ This development is achieved by interpreting the provisions in light of the context in which they were negotiated and in light of the context in which they are applied.

\subsection{Defining a "highly unstable coastline"}

If the decisive requirement for establishing straight baselines subsequent to Article $7(2)$ is that the coastline is "highly unstable", it is timely to discuss what highly unstable means in this context. Brown formulates the question elegantly: "What degree of change over what period of time would be considered to constitute a high degree of instability?" ${ }^{65}$ In light of climate change, the question can be further delineated to: How large must sea level fluctuations be to constitute a "highly unstable coastline"?

Hoque observes that the phrase "highly unstable" is not well understood and that it is not clear which criteria should be used to measure such instability ${ }^{66}$ However, Hoque does not contribute any further to analysing the content of the phrase. Prescott and Schofield, on the other hand, assert that the word 'unstable' "probably should be interpreted to mean that the location of the low-water line is highly variable in a horizontal plane" ${ }^{67}$ Therefore, the question arises: "what scale of movements might be described as highly unstable". ${ }^{68}$ Bird observes that, "[w] hile a few coastlines have advanced or retreated more than 100 metres per year, on the world scale a gain or loss of more than 
10 metres per year has been exceptionally rapid" ${ }^{69}$ Recalling from section 1 above, the IPCC predicts a global average sea level rise between 26 and 82 centimetres by the end of this century. ${ }^{70}$ It is also well-known that a one-metre rise will flood large areas of low-lying States, far greater than a ten-metre annual change in the coastline.

It is not clear where the threshold for a high degree of instability is, but it is quite clear from climate change research that sea level rise will have severe consequences for a number of low-lying and island-States, risking partial or complete submergence of mainland or island-territory and thereby also the loss of large maritime areas currently subject to national jurisdiction. Without concluding on the exact threshold of what makes up a high degree of instability, it seems clear that the predicted and experienced sea level rise are well above what constitutes a high degree of instability. Based on the above discussion, it is therefore concluded that coastal States which experience a highly unstable coastline due to sea level rise may establish straight baselines subject to Article 7(2).

\subsection{Permanent or ambulatory baselines?}

In addition to providing States with unstable coastlines with the opportunity to draw straight baselines along their coasts, Article 7(2) provides that such baselines shall "remain effective" in spite of subsequent regression of the low-water line. This suggests that straight baselines established under Article 7(2) are potentially less vulnerable to sea level change than normal baselines (Article 5) and straight baselines established on the basis of Article 7(1).

However, the LOSC does not seem to offer absolute permanency for delta baselines, as it provides that that the baselines shall remain effective "until changed by the coastal State in accordance with this Convention". ${ }^{71}$ The phrase "until changed" signals that the limits so established are not intended to be permanent and that, eventually, States are required to change their delta baselines. ${ }^{72}$ Soons raises the question whether "the coastal State is obliged to [change its delta baseline] at some point in time, in order to bring them in accordance with the changed factual situation, or whether it is entirely free in deciding to change or not to change the baseline". ${ }^{73} \mathrm{He}$ observes that it was not the intention of the provision to grant the coastal State discretionary power in this respect. If that were the case, he argues, it would not have been necessary to include a reference to subsequent change in the provision in the first place. ${ }^{74}$ Hoque shares Soons' view and observes that, whilst there is no time limit within which the baselines are to be revisited, it is quite natural that the coastal State will try to keep baselines in their original position for longer periods; if they were required to revise them immediately after the changed sea level or recession of the coast, the provision would not serve its purpose. ${ }^{75}$

However, some authors have interpreted Article 7(2) as optional for coastal States, if they would like to make changes to the deltaic baselines, as long as changes to baselines are in accordance with the LOSC. Di Leva and Morita observe that " $[t]$ his provision allows coastal states to change the baseline as long as such a change is in accordance with the Convention. If a State does not take any actions to change the baselines, 


\section{S. V. Busch}

however, the old baseline 'remains effective"' $\cdot{ }^{76}$ If the coastal State chooses not to change the baseline, the original baseline will remain effective in spite of sea level changes.

Stoutenburg asserts that Article 7(2) is far from fixing the baselines of unstable coasts and argues that the provision sanctions the continued validity of outdated baselines only until they are changed by the coastal State "in accordance with this convention" as prescribed in Article 7(2).$^{77}$ She observes that, "even in situations not falling under Art. 7(2) UNCLOS, in practice baselines once established and depicted on charts remain in place until the State decides to redraft the charts, even if the low-water line has in fact moved". ${ }^{78}$ Accordingly, there is not necessarily a significant difference between the degrees of permanency of straight baselines established under paragraphs 1 and 2 of Article 7. The difference, she argues, is that, for baselines established in accordance with Article 7(2), "this practice has been sanctioned by law, whereas in other cases states are under the legal obligation to adjust their baselines when necessary". ${ }^{79}$

Article 7(3) may provide some direction as to when baselines under Article 7(2) should be changed. Paragraph 3 is one of four paragraphs in Article 7 that places conditions for the construction of baselines and provides that " $[t]$ he drawing of straight baselines must not depart to any appreciable extent from the general direction of the coast" ${ }^{80}$ According to Prescott and Schofield, this condition applies to straight baselines established under both paragraphs 1 and $2 .{ }^{81}$ Reading Article 72(3) in connection with paragraph 2 , it can be argued that, when a coastline has changed dramatically, and the delta baseline departs to an appreciable extent from the general direction of the coast, the coastal State should adjust its delta baseline to be in conformity with the LOSC..$^{82}$ The UN study specifies that coastal States with straight baselines established subsequent to Article 7(2) are "not obliged to amend the basepoints for every charted change that takes place" after the limit has been established. ${ }^{83}$ But the basepoints will eventually be changed "when it becomes clear that the low-water line has significantly and permanently advanced or retreated from the position originally used". ${ }^{84}$

The ILA Committee is mindful of the relationship between Articles 7(3) and 7(2), and "notes the potential difficulty which may arise from a strict application of Article 7(3) to the circumstances outlined in Article 7(2)". The Committee continues that "a highly unstable coastline may be one in which determining the general direction of the coast may present significant challenges" ${ }^{85}$ Therefore, the Committee argues that the general direction criterion in Article 7(3), qualified by the words "to any appreciable extent", should "permit a margin of appreciation for a coastal State seeking to draw straight baselines along a high $[\mathrm{ly}]$ unstable coastline" ${ }^{86} \mathrm{~A}$ strict interpretation of Article 7(3) can potentially undermine the purpose of Article 7(2).

\subsection{The application of Article 7(2) in State practice}

In practice, application of Article 7(2) has been limited. Hoque observes that Bangladesh is "the only deltaic State that, more or less, tried to follow the spirit of Article 7(2)" ${ }^{87}$ Consequently, no State has to date changed its delta baselines, and it is not entirely clear how the provision will be interpreted and applied in the future. ${ }^{88}$ 
For comparison, the ILA Straight Baselines Study shows that 80 States have claimed straight baselines, 39 of which are subject to protests from other States. ${ }^{89}$ Prescott and Schofield observe:

It would be prudent for countries to review the coordinates defining their straight baselines at set intervals. This would ensure that any changes in the configuration of the low-water line can be recorded and the coordinates of basepoints adjusted. Finland seems to be the only country that specified in its declaration of its straight baselines that they would be reviewed every 30 years. ${ }^{90}$

General State practice on Article 7 demonstrates that, whilst many States have established straight baselines, few of them have followed the provisions of Article 7 to the letter. ${ }^{91}$ Most coastal States have relied on a liberal interpretation of the provision..$^{92}$ Due to this practice, the question then arises whether this has resulted in new customary law regarding straight baselines. Churchill observes that, although the number of non-conforming States is substantial, practice is diverse and does not point to any particular way in which straight baselines should be drawn. This, coupled with numerous protests over baseline claims, leads Churchill to the conclusion that "practice relating to the drawing of straight baselines does not amount either to an agreed interpretation of the Convention or a new rule of customary international law". ${ }^{93}$ This practice paints a different picture than the ICJ did in the Maritime Delimitation and Territorial Question between Qatar and Bahrain, where the ICJ observed: "This method must be applied restrictively" ${ }^{94}$ Churchill further observes that "there is no doubt (...) that such a relatively large amount of practice has weakened the authority of Article 7 of the Convention", and he acknowledges that "it must be admitted that the lack of precision in much of the article also weakens its normative status".$^{95}$ Although these statements reflect on application of Article 7 as a whole, it could be argued that Article 7(2) also suffers from the same lack of precision and therefore also has a weakened normative status.

The ILA Committee on Baselines observes that, even if State practice does not lead to a customary rule, the practice should be reviewed. It argues that, "[a]s a number of directly interested States have adopted a practice in respect of straight baselines that relies on a 'flexible' interpretation of Article 7, it should be assessed as an element of interpretation of the treaty provisions" ${ }^{96}$ This lends support the argument that a liberal and flexible interpretation of Article 7(2) potentially offers a solution for low-lying states exposed to sea level rise.

\section{Concluding remarks}

The physical consequences of sea level rise are most likely unavoidable for several coastal States due to their geographical location, size and topography. However, there is a certain amount of leeway within the LOSC that can contribute to increased stability and juridical protection of the maritime entitlements for some of the States suffering the consequences of sea level rise. 


\section{S.V.Busch}

Article 7 does not provide precise definitions for the key terms that allow for the establishment of straight baselines, giving rise to several significant queries. ${ }^{97}$ In practice, Article 7 has been interpreted flexibly, or even ignored by many coastal States, resulting in a proliferation of excessive claims to straight baselines. ${ }^{98}$ The ILA Committee on Baselines under the International Law of the Sea has acknowledged that "there is no agreed single interpretation of Article 7 or a new rule of customary international law". 99

Varied State practice on the interpretation and application of Article 7 in general, and the absolute lack of State practice on the application of Article 7(2) in particular, suggest that there may be room for a liberal interpretation and application of Article 7 (2) that will allow States with a highly unstable coastline due to sea level rise to draw more stable, straight baselines along their coasts. Based on the discussions above, it seems that the majority of legal scholars argue for such a liberal and flexible interpretation of the provision.

The current uncertainty in boundaries is highly undesirable and may foster conflicting claims to valuable ocean resources. ${ }^{100}$ An adapted interpretation of Article 7(2) as suggested in this paper would provide States with the opportunity to adapt to climate change and sea level rise, as well as contribute to preventing new conflicts concerning ocean resources without having to invoke the formal amendment procedures of the LOSC. Thus, it seems to be the most efficient way to counter the consequences of sea level rise for some vulnerable States.

Unfortunately, a liberal interpretation of Article 7(2) and the rules of baselines does not accommodate the needs of all States that are particularly vulnerable to sea level rise. For the group of Small Island Developing States, at risk of having one or more islands entirely submerged or rendered uninhabitable due to sea level rise, it seems unclear whether maritime limits may be upheld if the legal requirements for entitlement in Article 121 are no longer fulfilled. It can be argued that only where the requirements of Article 121 are met, does the question of the location of baselines and maintenance of permanent continental shelf limits come into play.

\section{NOTES}

1. Intergovernmental Panel for Climate Change (IPCC) reports 1-5, available at http://www. ipcc.ch/publications_and_data/publications_and_data_reports.shtml, latest entry 12.01.2018.

2. IPCC Fifth Assessment Report, Working Group I, Climate Change 2013 The Physical Science Basis, p. 1180, available at https:/www.ipcc.ch/pdf/assessment-report/ar5/wg1/WG1AR5_ Chapter13_FINAL.pdf latest entry 12.01.2018.

3. Ibid., 1191.

4. C Schofield and A Arsana, "Climate change and the limits of maritime jurisdiction", in Climate Change and the Oceans: Gauging the Legal and Policy Currents in the Asia Pacific and Beyond, ed. R Warner, C Schofield (Edward Elgar Publishing, 2012), 127.

5. DD Caron, "When Law Makes Climate Change Worse: Rethinking the Law of Baselines in Light of a Rising Sea Level", Ecology Law Quarterly, 17 (1990), 627; and C Schofield, "Holding back the waves? Sea level rise and maritime claims" in Climate Change: International 
Law and Global Governance: Legal Responses and Global Responsibility, ed. OC Ruppel, C Roschmann and K Ruppel-Schlichting, Vol.1 (2013), 593.

6. JG Stoutenburg, Disappearing Island States in International Law (Brill, Leiden, 2015), 38.

7. The Montevideo Convention on the Rights and Duties of States, in force 1934, LNTS 165(19), Article 1 (b).

8. United Nations Convention on the Law of the Sea, 1982, Entry into force 1994, UNTS 1833: 3. Hereinafter referred to as LOSC.

9. DD Caron, "When Law makes Climate Change Worse: Rethinking the Law of Baselines in Light of a Rising Sea-level", 621; AHA Soons, "The effects of sea-level rise on maritime limits and boundaries", Netherlands International Law Review 37 (1990), 207; C Schofield, "Holding back the waves? Sea level rise and maritime claims"; J McAdam, Climate Change, Forced Migration, and International Law (Oxford University Press, New York, 2012); JG Stoutenburg, Disappearing Island States in International Law; R Rayfuse, "Sea Level Rise and Maritime Zones: Preserving the Maritime Entitlement of 'Disappearing' States”, in Threatened Island Nations: Legal Implications of Rising Seas and a Changing Climate, ed. MB Gerrard and GE Wannier (Cambridge University Press, Cambridge, 2013).

10. DD Caron, "When Law makes Climate Change Worse: Rethinking the Law of Baselines in Light of a Rising Sea-level", 621.

11. AHA Soons, "The effects of sea-level rise on maritime limits and boundaries", 207.

12. See also C Schofield, "Holding back the waves? Sea level rise and maritime claims"; J McAdam, Climate Change, Forced Migration, and International Law; JG Stoutenburg, Disappearing Island States in International Law; R Rayfuse, "Sea Level Rise and Maritime Zones: Preserving the Maritime Entitlement of «Disappearing» States".

13. LOSC art. 13.

14. LOSC art. 7.

15. LOSC art. 7(3).

16. LOSC art. 7(4).

17. LOSC art. 7(6).

18. BB Jia, "The Principle of the Domination of the Land over the Sea: A Historical Perspective on the Adaptability of the Law of the Sea to New Challenges", IILJ Colloquim (2015), available at http://www.iilj.org/wp-content/uploads/2016/09/JiaIILJColloq2015.pdf, latest entry 12.01 .2018$.

19. LOSC art. 2(1).

20. AHA Soons, "The effects of sea-level rise on maritime limits and boundaries", 217; DD Caron, "When Law makes Climate Change Worse: Rethinking the Law of Baselines in Light of a Rising Sea-level", 635; SV Busch, Establishing Continental Shelf Limits Beyond 200 nautical Miles by the Coastal State - A Right of Involvement for Other States, Brill 2016, 315; R Rayfuse, "W(h)ither Tuvalu? International Law and Disappearing States", University of New South Wales Faculty of Law Research Series, Paper 9, 2009.

21. SV Busch, Establishing Continental Shelf Limits Beyond 200 Nautical Miles by the Coastal State - A Right of Involvement for Other States, 316.

22. Soons 1990, 217; Caron 1990, 635;

23. C Schofield and D Freestone, "Options to Protect Coastlines and Secure Maritime Jurisdictional Claims in the Face of Global Sea Level Rise", 144.

24. Ibid., 160; AHA Soons, "The effects of sea-level rise on maritime limits and boundaries".

25. R Rayfuse, "International Law and Disappearing States: Utilising Maritime Entitlements to Overcome the Statehood Dilemma", UNSW Law Research Paper 52 (2010).

26. AHA Soons, "The effects of sea-level rise on maritime limits and boundaries", 227. However, S Árnadóttir challenges the view of Soons and oppositely argues that "treaties 


\section{S.V.Busch}

establishing boundaries to the exclusive economic zone, exclusive fisheries zone and the continental shelf can be subject to termination due to a fundamental change of circumstances". (S Árnadóttir, "Termination of Maritime Boundaries Due to a Fundamental Change of Circumstances", in 32 (83) Utrecht fournal of International and European Law, 94 (2016), 96.

27. J Lisztwan, "Stability of Maritime Boundary Agreements", Yale fournal of International Law, 37:1 (2012), 180.

28. C Schofield and D Freestone, "Options to Protect Coastlines and Secure Maritime Jurisdictional Claims in the Face of Global Sea Level Rise", 150.

29. A Boyle, "Further Development of the Law of the Sea Convention: Mechanisms for Change", International and Comparative Law Quarterly, 54 (2005), 563-584.

30. "Bangladesh Position on the Question of Baseline", Caracas Session 1974, Reproduced in R Platzöder, Third United Nations Conference on the Law of the Sea: Documents, vol. IV (Oceana Publications, New York, 1983), 179.

31. "Revised Consolidated Text on Baselines", C.2/Blue Paper No. 4, 9 April 1975, Reproduced in R Platzöder, Third United Nations Conference on the Law of the Sea: Documents, vol. IV (Oceana Publications, New York, 1983), 126.

32. E Bird and V Prescott, "Rising Global Sea Levels and National Maritime Claims", Marine Policy Reports, 1 (1989) 192; JA Roach and RW Smith, Excessive Maritime Claims, 3rd edition, (Brill, 2012) 67; ED Brown, The International Law of the Sea, vol. 1 (Darthmouth Pulishing, 1994), 27.

33. Currently known as the United Nations Division for Ocean Affairs and the Law of the Sea (UNDOALOS).

34. UNDOALOS, Baselines: An Examination of the Relevant Provisions of the United Nations Convention on the Law of the Sea (United Nations Publications, 1989), 24.

35. WM Reisman and GS Westerman, Straight Baselines in Maritime Boundary Delimitation, (St. Martin's Press, New York, 1992), 101; see also JA Roach and RW Smith, Excessive Maritime Claims, 67; A Bateman and C Schofield, "State Practice Regarding Straight Baselines in East Asia - Legal, Technical and Political Issues in a Changing Environment", Paper prepared for international conference arranged by ABLOS (Monaco, 2008), 4, available at https:// www.iho.int/mtg_docs/com_wg/ABLOS/ABLOS_Conf5/Papers/Session7-Paper1-Bateman. pdf, last entry 12.01.2018).

36. C Schofield and B Sas, "Uncovered and Unstable Coasts, Climate Change and Territorial Baselines in the Arctic", in International Law and Politics of the Arctic Ocean, Essays in Honour Of Donat Pharand, ed. S Lalond og TL McDorman, (Brill, 2015), 297.

37. RR Churchill and AV Lowe, The Law of the Sea, $3^{\text {rd }}$ edition, (Manchester University Press, 1999), 38. See also A Bateman and C Schofield, "State Practice Regarding Straight Baselines in East Asia - Legal, Technical and Political Issues in a Changing Environment", in footnote 17.

38. V Prescott and C Schofield, Maritime Political Boundaries of the World, (Brill 2004), 151.

39. MN Hoque, The Legal and Scientific Assessment of Bangladesh's Baseline in the Context of Article 76 of the United Nations Convention on the Law of the Sea, (2005-2006) DOALOS, 76. Available at http://www.un.org/depts/los/nippon/unnff_programme_home/fellows_pages/fellows_papers/hoque_0506_bangladesh.pdf, latest entry 12.01.2018.

40. Ibid., 76 .

41. International Law Association, Committee on Baselines under the International Law, Washington Conference (2014), para. 6.

42. Ibid., para. 62 .

43. Ibid., paras. 24-25.

44. Ibid. 
45. "Revised Consolidated Text on Baselines", C.2/Blue Paper No. 4, 9 April 1975, reproduced in R Platzöder, Third United Nations Conference on the Law of the Sea: Documents, vol. IV (Oceana Publications, New York, 1983), 126.

46. ED Brown, The International Law of the Sea, 27.

47. RR Churchill and AV Lowe, The Law of the Sea, 37.

48. Ibid., 37.

49. MN Hoque, The Legal and Scientific Assessment of Bangladesh's Baseline in the Context of Article 76 of the United Nations Convention on the Law of the Sea, 72.

50. UNDOALOS, Baselines: An Examination of the Relevant Provisions of the United Nations Convention on the Law of the Sea, 24.

51. E Bird and V Prescott, "Rising Global Sea Levels and National Maritime Claims", 192. See also the Revised Consolidated Text at https://www.cia.gov/library/readingroom/docs/CIARDP82S00697R000400040004-8.pdf, latest entry 12.01.2018.

52. JG Stoutenburg, Disappearing Island States in International Law, 133.

53. RR Churchill and AV Lowe, The Law of the Sea, 37.

54. AJ Roach and RW Smith, "Straight Baselines: The Need for a Universally Applied Norm", Ocean Development E International Law, 31 (2000) 31:47, 51.

55. International Law Association, Committee on Baselines under the International Law, Washington Conference (2014), para. 24.

56. Ibid, para. 25 .

57. AG Oude Elferink, “The South China Sea Arbitration's Interpretation of Article 121(3) of the LOSC: A Disquieting First", JCLOS Blog (September 7, 2016) available on http://site. uit.no/jclos/files/2016/09/The-South-China-Sea-Arbitrations-Interpretation-of-Article1213-of-the-LOSC-A-Disquieting-First.pdf, 4.

58. Ibid, 5 .

59. UNDOALOS, Baselines: An Examination of the Relevant Provisions of the United Nations Convention on the Law of the Sea, 53.

60. V Prescott and C Schofield, Maritime Political Boundaries of the World, 154.

61. E Bird and V Prescott, "Rising Global Sea Levels and National Maritime Claims", 189.

62. RR Churchill and AV Lowe, The Law of the Sea, 38.

63. C Schofield and D Freestone, "Options to protect the coastline", 159.

64. LOSC, preamble.

65. ED Brown, The International Law of the Sea, 27; See also S Sefrioui, "Adapting to Sea Level Rise: A Law of the Sea Perspective", in The Future of the Law of the Sea, Bridging Gaps Between National, Individual and Common Interests, ed. G Andreone (ed) (Springer Open, 2017), 17.

66. MN Hoque, The Legal and Scientific Assessment of Bangladesh's Baseline in the Context of Article 76 of the United Nations Convention on the Law of the Sea, 72.

67. V Prescott and C Schofield, Maritime Political Boundaries of the World, 154.

68. Ibid.

69. ECF Bird, Coastline changes: a global review (John Wiley and Sons, New York, 1985), 158.

70. IPCC Fifth Assessment Report, 1180.

71. LOSC art. 7(2).

72. RR Churchill and AV Lowe, The Law of the Sea, 38; see also WM Reisman and GSWesterman, Straight Baselines in Maritime Boundary Delimitation.

73. AHA Soons, "The Effects of a Rising Sea Level on Maritime Limits and Boundaries", 220; see also JA Roach and RW Smith, Excessive Maritime Claims, 67.

74. AHA Soons, "The Effects of a Rising Sea Level on Maritime Limits and Boundaries", 220.

75. MN Hoque, The Legal and Scientific Assessment of Bangladesh's Baseline in the Context of Article 76 of the United National Convention on the Law of the Sea, 73. 


\section{S.V.Busch}

76. C Di Leva and S Morita, "Maritime Rights of Coastal States and Climate Change: Should States Adapt to Submerged Boundaries", in Law and Development Working Paper Series Legal Vice Presidency The World Bank, 5 (2008) 18.

77. JG Stoutenburg, Disappearing Island States in International Law, 132.

78. Ibid.

79. Ibid., p. 133.

80. LOSC art. 72(3).

81. V Prescott and C Schofield, Maritime Political Boundaries of the World, 156.

82. AHA Soons, "The Effects of a Rising Sea Level on Maritime Limits and Boundaries", 220; See also UNDOALOS, Baselines: An Examination of the Relevant Provisions of the United Nations Convention on the Law of the Sea, 24.

83. UNDOALOS, Baselines: An Examination of the Relevant Provisions of the United Nations Convention on the Law of the Sea, 24.

84. Ibid.

85. International Law Association, Committee on Baselines under the International Law, Washington Conference (2014), para. 62.

86. Ibid, para. 62 .

87. MN Hoque, The Legal and Scientific Assessment of Bangladesh's Baseline in the Context of Article 76 of the United National Convention on the Law of the Sea, 78; see also International Law Association, Committee on Baselines Under the International Law, Washington Conference (2014), para. 34-35.

88. C Di Leva and S Morita, "Maritime Rights of Coastal States and Climate Change: Should States Adapt to Submerged Boundaries", 18.

89. International Law Association Straight Baselines Study, Draft 13 November 2016, available at http://www.ila-hq.org/index.php/committees, latest entry 12.01.2018.

90. V Prescott and C Schofield, Maritime Political Boundaries of the World, 161

91. MN Hoque, The Legal and Scientific Assessment of Bangladesh's Baseline in the Context of Article 76 of the United National Convention on the Law of the Sea, 36.

92. Ibid.

93. RR Churchill, "The Impact of State Practice on the Jurisdictional Framework Contained in the LOSC Convention" in Stability and Change in the Law of the Sea:The Role of the LOSC Convention, ed. AG Oude Elferink (Martinus Nijhoff Publishers, 2005), 108; See also International Law Association, Committee on Baselines Under the International Law, Washington Conference (2014), para. 60.

94. Maritime Delimitation and Territorial Question between Qatar and Bahrain, Merits, Judgment, 2001 ICJ Rep. 40, at 67, para. 212

95. Ibid, 108-109.

96. International Law Association, Committee on Baselines under the International Law, Washington Conference (2014), para. 41

97. A Bateman and C Schofield, "State Practice Regarding Straight Baselines in East Asia - Legal, Technical and Political Issues in a Changing Environment", 5.

98. A Bateman and C Schofield, "State Practice Regarding Straight Baselines in East Asia - Legal, Technical and Political Issues in a Changing Environment", 5.

99. International Law Association, Committee on Baselines under the International Law, Washington Conference (2014), para. 60.

100. DD Caron, "Climate Change, Sea Level Rise and the Coming Uncertainty in Oceanic Boundaries: A Proposal to Avoid Conflict", in Maritime Boundary Disputes, Settlement Processes and the Law of the Sea, ed. S-Y Hong and JMVan Dyke (Martinus Nijhoff Publishers, 2009). 


\section{REFERENCES}

Árnadóttir, S., "Termination of Maritime Boundaries Due to a Fundamental Change of Corcumstances", in 32 (83) Utrecht fournal of International and European Law 94 (2016).

Bateman, A. and Schofield, C., "State Practice regarding Straight Baselines in East Asia - Legal, Technical and Political Issues in a Changing Environment", Paper prepared for international conference arranged by ABLOS (Monaco, 2008), 4, available at https://www.iho.int/mtg_docs/ com_wg/ABLOS/ABLOS_Conf5/Papers/Session7-Paper1-Bateman.pdf, last entry 12.01.2018).

Bird, E. and Prescott, V., "Rising Global Sea Levels and National Maritime Claims", Marine Policy Reports, 1 (1989) 192; JA Roach and RW Smith, Excessive Maritime Claims, 3rd edition, (Brill, 2012).

Bird, E., Coastline changes: a global review (John Wiley and Sons, New York, 1985).

Boyle, A., "Further Development of the Law of the Sea Convention: Mechanisms for Change", International and Comparative Law Quarterly, 54 (2005).

Brown, ED., The International Law of the Sea, vol. 1 (Darthmouth Pulishing, 1994).

Busch, SV., Establishing Continental Shelf Limits Beyond 200 Nautical Miles by the Coastal State - A Right of Involvement for Other States, Brill 2016.

Caron, DD., "Climate Change, Sea Level Rise and the Coming Uncertainty in Oceanic Boundaries: A Proposal to Avoid Conflict", in Maritime Boundary Disputes, Settlement Processes and the Law of the Sea, ed. S-Y Hong and JM Van Dyke (Martinus Nijhoff Publishers, 2009).

Caron, DD., "When Law Makes Climate Change Worse: Rethinking the Law of Baselines in Light of a Rising Sea Level”, Ecology Law Quarterly, 17 (1990).

Churchill, RR. and Lowe, AV., The Law of the Sea, 3rd edition, (Manchester University Press, 1999).

Churchill, RR., "The impact of State practice on the Jurisdictional Framework Contained in the LOSC Convention" in Stability and Change in the Law of the Sea:The Role of the LOSC Convention, ed. AG Oude Elferink (Martinus Nijhoff Publishers, 2005).

Di Leva, C. and Morita, S., "Maritime Rights of Coastal States and Climate Change: Should States Adapt to Submerged Boundaries", in Law and Development Working Paper Series Legal Vice Presidency The World Bank, 5 (2008).

Hoque, MN., The Legal and Scientific Assessment of Bangladesh's Baseline in the Context of Article 76 of the United Nations Convention on the Law of the Sea, (2005-2006) DOALOS. Available at http:// www.un.org/depts/los/nippon/unnff_programme_home/fellows_pages/fellows_papers/ hoque_0506_bangladesh.pdf, latest entry 12.01.2018.

Intergovernmental Panel for Climate Change (IPCC) reports 1-5, available at http://www.ipcc.ch/ publications_and_data/publications_and_data_reports.shtml, latest entry 12.01.2018.

International Law Association Straight Baselines Study, Draft 13 November 2016, available at http:// www.ila-hq.org/index.php/committees, latest entry 12.01.2018.

International Law Association, Committee on Baselines under the International Law of the Sea, Washington Conference (2014), available at http://www.ila-hq.org/index.php/committees latest entry 12.01.2018

IPCC Fifth Assessment Report, Working Group I, Climate Change 2013 The Physical Science Basis, p. 1180, available at https://www.ipcc.ch/pdf/assessment-report/ar5/wg1/WG1AR5_Chapter13_ FINAL.pdf latest entry 12.01.2018.

Jia, BB., "The Principle of the Domination of the Land over the Sea: A Historical Perspective on the Adaptability of the Law of the Sea to New Challenges", IILJ Colloquim (2015), available at http://www.iilj.org/wp-content/uploads/2016/09/JiaIILJColloq2015.pdf, latest entry 12.01.2018.

Lisztwan, J., "Stability of Maritime Boundary Agreements", Yale fournal of International Law, 37:1 (2012).

Maritime Delimitation and Territorial Question between Qatar and Bahrain, Merits, Judgment, 2001 ICJ Rep. 40, at 67, para. 212 


\section{S.V.Busch}

McAdam, J., Climate Change, Forced Migration, and International Law (Oxford University Press, New York, 2012).

Oude Elferink, AG., "The South China Sea Arbitration's Interpretation of Article 121(3) of the LOSC: A Disquieting First", JCLOS Blog (September 7, 2016) available on http://site.uit.no/ jclos/files/2016/09/The-South-China-Sea-Arbitrations-Interpretation-of-Article-1213-of-theLOSC-A-Disquieting-First.pdf, latest entry 09.02.1018.

Platzöder, R., "Bangladesh Position on the Question of Baseline", Caracas Session 1974, Reproduced in R Platzöder, Third United Nations Conference on the Law of the Sea: Documents, vol. IV (Oceana Publications, New York, 1983), 179.

Platzöder, R., "Revised Consolidated Text on Baselines", C.2/Blue Paper No. 4, 9 April 1975, Reproduced in R Platzöder, Third United Nations Conference on the Law of the Sea:Documents, vol. IV (Oceana Publications, New York, 1983), 126.

Prescott, V. and Schofield, C., Maritime Political Boundaries of the World, (Brill 2004).

Rayfuse, R., "International Law and Disappearing States: Utilising Maritime Entitlements to Overcome the Statehood Dilemma", UNSW Law Research Paper 52 (2010).

Rayfuse, R., "Sea Level Rise and Maritime Zones: Preserving the Maritime Entitlement of «Disappearing»" States", in Threatened Island Nations: Legal Implications of Rising Seas and a Changing Climate, ed. MB Gerrard and GE Wannier (Cambridge University Press, Cambridge, 2013).

Rayfuse, R., "W(h)ither Tuvalu? International Law and Disappearing States", University of New South Wales Faculty of Law Research Series, Paper 9, 2009.

Reisman, WM. and Westerman, GS., Straight Baselines in Maritime Boundary Delimitation, (St. Martin's Press, New York, 1992).

Roach, AJ. and Smith, RW., "Straight Baselines: The Need for a Universally Applied Norm", Ocean Development \& International Law, 31 (2000) 31:47.

Roach, JA. and Smith, RW., Excessive Maritime Claims, 3rd edition, (Brill, 2012).

Schofield, C. and Arsana, A., "Climate change and the limits of maritime jurisdiction", in Climate Change and the Oceans: Gauging the Legal and Policy Currents in the Asia Pacific and Beyond, ed. R Warner, C Schofield (Edward Elgar Publishing, 2012).

Schofield, C. and Freestone, D., "Options to Protect Coastlines and Secure Maritime Jurisdictional Claims in the Face of Global Sea Level Rise", in Threatened Island Nations, ed. MB Gerrard and GE Wannier, (Cambridge University Press, 2013).

Schofield, C. and Sas, B., "Uncovered and Unstable Coasts, Climate Change and Territorial Baselines in the Arctic", in International Law and Politics of the Arctic Ocean, Essays in Honour Of Donat Pharand, ed. S Lalond og TL McDorman, (Brill, 2015).

Schofield, C., "Holding back the waves? Sea level rise and maritime claims" in Climate Change: International Law and Global Governance: Legal Responses and Global Responsibility, ed. OC Ruppel, C Roschmann og K Ruppel-Schlichting, Vol.1 (2013).

Sefrioui, S., "Adapting to Sea Level Rise: A Law of the Sea Perspective", in The Future of the Law of the Sea, Bridging Gaps Between National, Individual and Common Interests, ed. G Andreone (ed) (Springer Open, 2017).

Soons, AHA., "The effects of sea level rise on maritime limits and boundaries", Netherlands International Law Review 37 (1990).

Stoutenburg, JG., Disappearing Island States in International Law (Brill, Leiden, 2015).

The Montevideo Convention on the Rights and Duties of States, in force 1934, LNTS 165(19).

UNDOALOS, Baselines: An Examination of the Relevant Provisions of the United Nations Convention on the Law of the Sea (United Nations Publications, 1989).

United Nations Convention on the Law of the Sea, 1982, Entry into force 1994, UNTS 1833(3). 